\title{
Ammonium Homeostasis and Human Rhesus Glycoproteins
}

\author{
Gabrielle Planelles \\ Inserm, U806 et Université Paris Descartes, Faculté de Médecine René Descartes, Paris, France
}

\section{Key Words}

Rhesus proteins $\cdot$ Kidney, ammonium production $\cdot$ Renal

tubule - Ammonia - Ammonium - Carbon dioxide •

Oocyte $\cdot$ Membrane transport

\begin{abstract}
The brain ammonium production is detoxified by astrocytes, the gut ammonium production is detoxified by hepatic cells, and the renal ammonium production plays a major role in renal acid excretion. As a result of ammonium handling in these organs, the ammonium and $\mathrm{pH}$ values are strictly regulated in plasma. Up until recently, it was accepted that mammalian cell transmembrane ammonium transport was due to $\mathrm{NH}_{4}{ }^{+}$transport by non-specific transporting systems, and to non-ionic $\mathrm{NH}_{3}$ diffusion, whereas lower organisms (such as bacteria, yeasts and plants) were endowed with specific ammonium transporters (Amts). Sequence homologies between Amts and human Rhesus (Rh) glycoproteins (RhAG, from erythroid cells, and RhBG and RhCG from epithelial cells) raised the hypothesis that Rh glycoproteins act as specific ammonium transporters, further sustained by the polarized distribution of RhBG and RhCG in gut, kidney and liver. Results from functional studies agree that Rh glycoproteins are the first ammonium transporters reported in mammals. However, the nature of the transported specie(s) is much debated: in particular, it is proposed that Rh glycoproteins mediate a direct $\mathrm{NH}_{3}$ transport, or that they mediate an indirect $\mathrm{NH}_{3}$ transport (resulting from $\mathrm{NH}_{4}^{+}$for $\mathrm{H}^{+}$ex-
\end{abstract}

change). Direct $\mathrm{NH}_{3}$ transport (associated or not with $\mathrm{NH}_{4}{ }^{+}$ transport) raises the exciting hypothesis that $\mathrm{Rh}$ glycoproteins may also transport other gasses than $\mathrm{NH}_{3}$ (namely, $\mathrm{CO}_{2}$ ).

\section{Introduction}

In aqueous ammonium-containing solution, the ionic (ammonium ions, $\mathrm{NH}_{4}^{+}$) and the non-ionic (ammonia, $\mathrm{NH}_{3}$ ) forms of ammonium ${ }^{1}$ are in chemical equilibrium; their respective concentrations regarding the total ammonium concentration depend on the fluid $\mathrm{pH}$. Due to the high apparent $\mathrm{pK}$ of $\mathrm{NH}_{3} / \mathrm{NH}_{4}{ }^{+}, \mathrm{NH}_{4}{ }^{+}$is the predominant form in mammalian fluids (about $97-98 \%$ of total ammonium). In several body epithelial compartments, such as the intestinal or the nephron lumen, the ammonium concentration is in the millimolar range, whereas it is $<100 \mu \mathrm{M}$ in plasma. Any increase in blood ammonium level, for example during hepatic dysfunction, may

\footnotetext{
1 In this text, 'ammonium' means 'total ammonium', i.e., $\mathrm{NH}_{3}+\mathrm{NH}_{4}{ }^{+}$, and is used when ammonia (gas) and ammonium ions are not distinguished. When necessary, the chemical symbols for ammonia $\left(\mathrm{NH}_{3}\right)$ and ammonium ions $\left(\mathrm{NH}_{4}^{+}\right)$are used to distinguish the two forms of ammonium. The equilibrium reaction of $\mathrm{NH}_{3} / \mathrm{NH}_{4}{ }^{+}$is given by the HendersonHasselbach equation applied to ammonium buffer: $\mathrm{pH}=\mathrm{pKa}+\log \left(\left[\mathrm{NH}_{3}\right] /\right.$ $\left[\mathrm{NH}_{4}^{+}\right]$). In aqueous solutions, $\mathrm{pKa}=9.246$ at $25^{\circ} \mathrm{C}$ and 8.891 at $37^{\circ} \mathrm{C}$ (calculated from Appendix 12.1, table 1 [cf. 1]). In plasma, pKa is 9.01 [2].
}

\section{KARGER}

Fax +4161306 1234 E-Mail karger@karger.ch www.karger.com
(C) 2007 S. Karger AG, Basel $1660-2137 / 07 / 1051-0011 \$ 23.50 / 0$

Accessible online at:

www.karger.com/nep
Gabrielle Planelles

Université Paris Descartes, Paris 5, Faculté de Médecine René Descartes

156 rue de Vaugirard

F-75730 Paris (France)

Tel. +33 14061 5620, Fax +33 14061 5591, E-Mail planelle@necker.fr 
severely disturb neuronal function, whereas an increase in urinary ammonium excretion fights against chronic metabolic acidosis (CMA). Before recent studies on Rhesus glycoproteins, it was accepted that the transmembrane transport of $\mathrm{NH}_{4}{ }^{+}$in mammalian cells is mediated by membrane transport systems that are not specific to ammonium, and that $\mathrm{NH}_{3}$ freely crosses biological membranes. The cloning of the erythroid Rhesus-associated glycoprotein, RhAG (previously named Rh50, due to its molecular weight) was followed by the cloning of two non-erythroid homologues, RhBG and RhCG (previously named RhGK) that are expressed in epithelial structures, but not in erythroid cells. Functional studies from several laboratories revealed that human $\mathrm{Rh}$ glycoproteins RhAG, RhCG and RhCG (and/or their mouse orthologs, Rhag, Rhbg and Rhcg, respectively) are ammonium transporters. However, $\mathrm{NH}_{4}{ }^{+}$versus $\mathrm{NH}_{3}$ transport by $\mathrm{Rh}$ glycoproteins is still hotly debated.

\section{Ammonium in the Human Body}

Ammonium production is mostly localized to the brain, kidney, and gut. In the central nervous system, the ammonium production is consequent to the metabolism of neurotransmitters. The most important pathway for ammonium production in the brain is the oxidative deamination of glutamate by the glutamate dehydrogenase. A large part of the neuronal production of ammonium is transformed by the astrocytes, thanks to glutamine synthetase (GS): the glutamine released from astrocytes enters into the glutamine-glutamate cycle at the glutamatergic neuronal endings. Also, ammonium diffuses from blood to the central nervous system by crossing the bloodbrain barrier, driven by the favorable ammonium chemical gradient (the precise ammonium concentration in the brain is not known with accuracy but is probably physiologically $\leq 50 \mu \mathrm{M}$ ) and by the $\mathrm{pH}$ gradient (brain $\mathrm{pH}$ is 7.1). An increase in blood ammonium concentration may rapidly (in particular during metabolic alkalosis) challenge the brain function by overloading the efficiency of the astrocytes to trap ammonium and convert it to glutamine. The subsequent increase in brain ammonium concentration (that may reach up to $\sim 5 \mathrm{mM}$ ) has deleterious 'toxic' effects: $\mathrm{NH}_{4}{ }^{+}$in excess permeates into neurons using $\mathrm{K}^{+}$and $\mathrm{Na}^{+}$channels [3]; this influx induces membrane depolarization, challenges neuronal excitability, disturbs intracellular metabolic and enzymatic reactions, and affects intracellular $\mathrm{pH}\left(\mathrm{pH}_{\mathrm{i}}\right)$ and cell-buffering power. Except for rare iatrogenic or metabolic-induced in- creases in blood ammonium concentration, hyperammonemic syndromes result from inherited errors in urea cycle enzymes, or from (acute or chronic) acquired failure of the liver functions. In normal conditions, the liver detoxifies the gut ammonium production that is delivered by the portal vein: several grams of ammonium are produced per day in the digestive tract, as a result of protein digestion and deamination processes, and of urea hydrolysis. In the liver, ammonium is enzymatically converted into urea or glutamine, an ammonium detoxification process that is achieved in one single pass. In normal acid-base conditions, the bulk of ammonium (about 90$95 \%$ ) is converted into urea by the periportal hepatocytes, which are endowed with the complete cycle of urea synthesis (carbamoyl phosphatase synthetase is a low-affinity system for ammonium, with a $\mathrm{K}_{\mathrm{m}} \sim 2 \mathrm{mM}$ ); during this process, bicarbonate ions (and glutamine) are consumed. Downstream, the ammonium escaping urea conversion is converted into glutamine by GS (a high-affinity system for ammonium, with a $\mathrm{K}_{\mathrm{m}} \sim 0.2 \mathrm{mM}$ ) in perivenous hepatocytes. During CMA, glutamine synthesis by perivenous hepatocytes is increased at the expense of the upstream ureagenesis: in that way, hepatic $\mathrm{HCO}_{3}{ }^{-}$ consumption is reduced, whereas removal (conversion) of $\mathrm{NH}_{4}{ }^{+}$is ensured. Thus, during CMA, the glutamine balance in the liver is not neutral: a net release of glutamine from liver to blood occurs. The liver glutamine cycle supports the idea of Haussinger [4] that the liver has a crucial role in acid-base homeostasis ${ }^{2}$.

In the kidney, ammonium production takes place mostly in the proximal tubular cells (endowed with GS). In these cells, ammonium production derived from glutamine that is taken up from blood:glutamine metabolism leads to glutamate or $\alpha$-ketoglutarate ${ }^{-}$, and to $\mathrm{NH}_{4}{ }^{+}$production. Interestingly, an end product of the $\alpha$-ketoglutarate ${ }^{-}$metabolism is $\mathrm{HCO}_{3}{ }^{-}$. Thus, renal ammonium synthesis in proximal cells leads to the formation of 'new' bicarbonate ions ${ }^{3}$, 'replacing' the bicarbonate ions consumed during the hepatic urea formation. $\mathrm{HCO}_{3}{ }^{-}$exit from cell to interstitium is ensured by the coupled basolateral transport of $\mathrm{Na}^{+}$and $\mathrm{HCO}_{3}{ }^{-}$via the renal $\mathrm{Na}^{+}-\mathrm{HCO}_{3}{ }^{-}$symport,

\footnotetext{
2 It should be emphasized that extrahepatic and extrarenal organs also play a role in acid-base balance and in ammonium homeostasis; in particular, skeletal muscles may metabolize (with low efficiency) ammonium that escapes hepatic detoxification, but can also produce ammonium during exercise.

3 Ammonium synthesis by proximal cells is increased during metabolic acidosis, but also during hypokalemia [7]. Whereas an increased ammonium production in proximal tubular cells is a sparing mechanism during CMA; it participates in maintaining the metabolic alkalosis associated with hypokalemia.
} 
kNBC. Ammonium ions are secreted in the proximal lumen by the apical NHE3, running in $\mathrm{Na}^{+} / \mathrm{NH}_{4}{ }^{+}$exchange mode [5]. Along Henle's loop, $\mathrm{NH}_{4}{ }^{+}$is reabsorbed from the lumen by taking the place of $\mathrm{K}^{+}$on the $\mathrm{Na}^{+}-\mathrm{K}^{+}-2 \mathrm{Cl}^{-}$symport, NKCC2. The renal counter-current mechanism concentrates ammonium in the renal inner medulla. Final excretion of ammonium in the distal lumen of the nephron follows $\mathrm{NH}_{3}$ secretion along the collecting tubules and ducts: this gas diffuses from the renal interstitium to the lumen, due to favorable driving forces (the $\mathrm{NH}_{3}$ transtubular chemical gradient, and the acid value of luminal $\mathrm{pH}$ ) across the epithelial cell barrier. In the lumen of the distal nephron, the weak base $\mathrm{NH}_{3}$ rapidly combines with protons to form the weak acid $\mathrm{NH}_{4}{ }^{+}$as shown in figure 1 [for review, see 6]. This allows not only the secretion of proton equivalents, but also affords a supplemental buffering power to the luminal fluid. With such processes, during CMA, an enhanced proton secretion (mediated by $\mathrm{H}^{+}-$ ATPases) occurs without inducing a tremendous decrease of luminal $\mathrm{pH}$ (deleterious to the renal cells, and also favoring nephrolithiasis), since the enhanced proton secretion is buffered by the enhanced $\mathrm{NH}_{4}{ }^{+}$excretion. Even during CMA, the urinary $\mathrm{NH}_{4}{ }^{+}$has a renal origin (see footnote 3); during this condition, urinary $\mathrm{NH}_{4}{ }^{+}$(increasing to $90 \mathrm{mM}$ ) may represent $90 \%$ of the renal acid excretion. Thus, urinary ammonium excretion is a major component of the net urinary acid excretion.

\section{Ammonium Transmembrane Transport}

Lower organisms are endowed with specific ammonium transporters from the $\mathrm{Amt}^{4}$ family. In higher organisms, it was accepted that $\mathrm{NH}_{4}{ }^{+}$is transported in an unspecific way by various transport systems, such as $\mathrm{K}^{+}$ channels, $\mathrm{Na} / \mathrm{K}$-ATPase, $\mathrm{Na}-\mathrm{K}-2 \mathrm{Cl}$ co-transport, $\mathrm{KCl}$ cotransport, non-selective cationic channels and the colonic $\mathrm{H}, \mathrm{K}-\mathrm{ATPa} e[8,9]$, that transport $\mathrm{NH}_{4}{ }^{+}$in the place of $\mathrm{K}^{+}$because hydrated $\mathrm{NH}_{4}{ }^{+}$and $\mathrm{K}^{+}$have a similar ionic radius, $1.45 \AA$ [10]. However, these transporters have a lower affinity for $\mathrm{NH}_{4}{ }^{+}$than for $\mathrm{K}^{+}$; thus the efficiency of $\mathrm{NH}_{4}{ }^{+}$transmembrane transport depends on the $\mathrm{NH}_{4}{ }^{+}$

\footnotetext{
4 Amts (ammonium transporters) are present in microorganisms (archea, bacteria, fungi, yeasts), plants and invertebrates [11]. The function(s) of Amts falls beyond the scope of this review. Contradictory literature has been reported recently as to the function of various Amt proteins and the conduction of ammonium ions, ammonia and/or $\mathrm{CO}_{2}$. The recent crystallization of Escherichia coli $\mathrm{AmtB}$ reveals a channel-like structure presenting an external $\mathrm{NH}_{4}{ }^{+}$binding site; $\mathrm{NH}_{3}$ conduction is a consequence of $\mathrm{NH}_{4}{ }^{+}$deprotonation along the channel hydrophobic pore $[12,13]$.
}

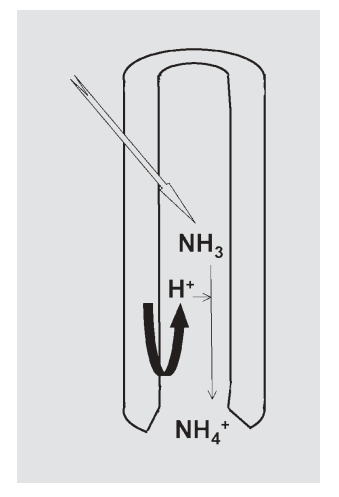

Fig. 1. Mechanism of $\mathrm{NH}_{4}{ }^{+}$excretion by distal nephron. High epithelium permeability to $\mathrm{NH}_{3}$, favorable transepithelial $\mathrm{NH}_{3}$ chemical gradient (due to ammonium accumulation in the renal medulla), and acid $\mathrm{pH}$ in the lumen allow $\mathrm{NH}_{3}$ secretion from the interstitium to the lumen. In the luminal fluid, $\mathrm{NH}_{4}{ }^{+}$formation is consecutive to $\mathrm{NH}_{3}$ protonation by actively secreted $\mathrm{H}^{+}$.

and $\mathrm{K}^{+}$respective concentrations in the medium: $\mathrm{NH}_{4}^{+}$ transmembrane transport is favored when $\left[\mathrm{NH}_{4}^{+}\right]$is high and/or $\left[\mathrm{K}^{+}\right]$is low. In epithelia involved in ammonium homeostasis, relatively high $\mathrm{NH}_{4}{ }^{+}$concentrations prevail in (at least) one given compartment ${ }^{5}$, making these mechanisms physiologically effective. Also, it was accepted that gasses (including $\mathrm{NH}_{3}$ ) freely diffuse across the lipid membranes. This diffusion depends on the gas chemical transmembrane gradient (driving force) and on the lipid properties of the cell membrane (permeability). However, several lines of experimental arguments have challenged the classical view of free diffusion of gas [for review, see 14]: a few cell membranes have a low permeability to gas, and several aquaporins enhance membrane permeability to $\mathrm{CO}_{2}$ or to $\mathrm{NH}_{3}$ [14-18].

Our current knowledge of ammonium transport has been revised by the discovery of Rhesus $(\mathrm{Rh})$ proteins. $\mathrm{Rh}$ genes (mostly found in invertebrates and in vertebrates) belong to the AMT/RH superfamily. The role in ammonium transport of the $\mathrm{Rh}$ proteins that are glycosated, RhAG, RhBG and RhCG, was first suggested due to sequence homologies with Amts [19]. First functional evidence was given by Marini et al. [20] in yeast with the endogenous methylammonium permeases (Mep) removed and transfected with Rh glycoproteins: growth of RhAG- and RhCG-expressing $\Delta$ Mep yeast was restored in a low ammonium-containing medium. The role of $\mathrm{Rh}$ glycoproteins in mammalian ammonium transport was further supported by immunolocalization studies [for review, see 21]: RhBG and RhCG are membrane proteins expressed in tissues involved in ammonium homeostasis and/or transport (in particular the digestive tract, the liv-

\footnotetext{
5 Only the transcellular ammonium transport is considered here; however, the paracellular transport in epitheliums is of low energetic cost, and contributes to transepithelial transport.
} 


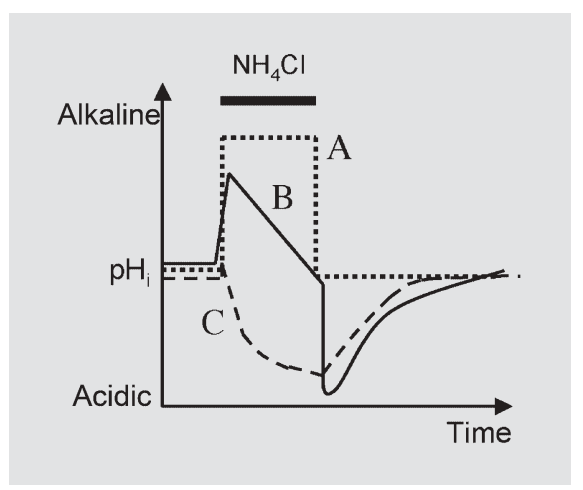

Fig. 2. Cell exposure to an ammonium-containing solution induces intracellular $\mathrm{pH}$ changes. Schematic representation of the possible $\mathrm{pH}_{\mathrm{i}}$ changes in cells exposed to millimolar concentrations of ammonium. Most cell membranes are highly permeable to $\mathrm{NH}_{3}$; the rapid diffusion of this weak base from the bath to the cell induces immediate cell alkalization, due to the (almost) total $\mathrm{NH}_{3}$ protonation into $\mathrm{NH}_{4}{ }^{+}$. Line A shows $\mathrm{pH}_{\mathrm{i}}$ change in a cell freely permeable to $\mathrm{NH}_{3}$ but totally impermeable to $\mathrm{NH}_{4}{ }^{+}$. Line $\mathrm{B}$ shows the very common feature of $\mathrm{pH}_{\mathrm{i}}$ changes in a cell that is permeable to both $\mathrm{NH}_{3}$ and $\mathrm{NH}_{4}{ }^{+}$: the immediate alkalization (consecutive to $\mathrm{NH}_{3}$ influx) is followed by a secondary acidification that reflects $\mathrm{NH}_{4}{ }^{+}$influx (cell acidification is related to intracellular $\mathrm{NH}_{4}{ }^{+}$partial dissociation into $\mathrm{NH}_{3}$ and $\mathrm{H}^{+}$). The more permeable the cell membrane to $\mathrm{NH}_{4}^{+}$, the more pronounced is the amplitude of the secondary re-acidification. Line $\mathrm{C}$ shows the $\mathrm{pH}_{\mathrm{i}}$ change observed in a cell that is almost impermeable to $\mathrm{NH}_{3}$, but highly permeable to $\mathrm{NH}_{4}{ }^{+}$, as is the case of the $\mathrm{X}$. laevis oocyte (for more details on oocyte membrane permeability to $\mathrm{NH}_{3}$ and $\mathrm{NH}_{4}{ }^{+}$, see Cougnon et al. [8]): the initial alkalization is blunted by an almost immediate acidification.

er, and the kidney). Interestingly, in the liver, $\mathrm{RhBG}$ is selectively expressed in the plasma membrane of periportal hepatocytes; because these cells are endowed with the high-affinity GS, they are expected to be endowed with an efficient plasma membrane mechanism allowing ammonium influx. In the kidney, RhBG and RhCG are colocalized along the distal nephron (with a particularly strong expression in acid-secreting A cells, but not in B cells) [21]. They are expressed with opposite cell polarity (RhBG in the basolateral membrane, RhCG in the apical membrane), supporting a coordinate role in net ammonium transcellular transport.

\section{Studying the Function of Rhesus Glycoproteins}

From the first report from Marini et al. [20], several functional studies confirmed the role of Rh glycoproteins in ammonium transport. With the exception of a study performed in red cell ghosts [22], most functional studies were performed after the heterologous expression of $\mathrm{Rh}$ glycoproteins. As detailed below, all studies agree to conclude that Rh glycoproteins are the first specific ammonium transporters reported in mammals. However, the mechanism of transport (transporter, channel, channellike protein) mediated by $\mathrm{Rh}$ glycoproteins and the nature of the transported substrate(s) $\left(\mathrm{NH}_{4}{ }^{+}\right.$and/or $\mathrm{NH}_{3}$ or $\mathrm{H}^{+}$) are controversial.

There is no direct approach to monitor a protein-mediated transport of ammonium. Functional approaches measured (i) methylammonium fluxes, (ii) ammoniuminduced $\mathrm{pH}_{\mathrm{i}}$ changes, and/or (iii) ammonium-induced current in voltage-clamped Xenopus laevis oocytes. All of them have technical or conceptual limitations. Labeled methylammonium, $\mathrm{CH}_{3} \mathrm{NH}_{2} / \mathrm{CH}_{3} \mathrm{NH}_{3}{ }^{+}$(MeA), used as a surrogate for ammonium fluxes, is not a perfect tracer for ammonium (transporter affinities for methylammonium and ammonium differ, and $\mathrm{pKa}$ for $\mathrm{MeA}$ is higher than for ammonium, 10.65 versus 9.25). In several studies (see below), a lack of effect of voltage change on MeA flux was considered as a strong argument in favor of electroneutral ammonium transport, but this may be an overinterpretation. A pH effect on MeA flux may be due to a direct effect, to a change in transmembrane proton gradient, or to a change in the neutral form concentration of $\mathrm{MeA}$ (at the same $\mathrm{pH}_{\mathrm{o}}$ and for the same MeA and ammonium total concentration, $\left[\mathrm{CH}_{3} \mathrm{NH}_{2}\right]$ is $<\left[\mathrm{NH}_{3}\right]$ whereas $\left[\mathrm{CH}_{3} \mathrm{NH}_{3}^{+}\right] \sim\left[\mathrm{NH}_{4}^{+}\right]$, due to the difference in respective $\mathrm{pKa}$ ). Analysis of ammonium-induced changes in intracellular $\mathrm{pH}$ is the most widely used approach to assess $\mathrm{NH}_{3}$ and $\mathrm{NH}_{4}{ }^{+}$fluxes. Figure 2 shows schematically the various $\mathrm{pH}_{\mathrm{i}}$ changes (determined using a $\mathrm{pH}$ fluorescent probe or $\mathrm{pH}$-selective microelectrodes) during cell exposure to millimolar concentrations of ammonium. Ammonium-induced initial $\mathrm{pH}_{\mathrm{i}}$ changes as a function of time $\left(\mathrm{dpH}_{\mathrm{i}} / \mathrm{dt}\right)$ are an index ${ }^{6}$ of $\mathrm{NH}_{3}$ influx (alkalizing phase) and of $\mathrm{NH}_{4}{ }^{+}$influx (acidifying phase) from bath to cell. Accuracy of this determination depends on the sensitivity and rapidity of the technique used to measure $\mathrm{pH}_{\mathrm{i}}$ changes. Also, ammonium-induced inward currents in voltage-clamped oocytes (measured at negative holding potentials, in general $-50 \mathrm{mV}$ ) are used as an index of $\mathrm{NH}_{4}{ }^{+}$transport. A main concern in the interpretation of ammonium-induced current is to discriminate between a current related to $\mathrm{NH}_{4}{ }^{+}$transport directly mediated by the expressed protein, a current specifically associated to

6 Ammonium flux, $\Phi$ Amm, is $\Phi A \mathrm{~mm}=\mathrm{dpH}_{\mathrm{i}} / \mathrm{dt} \cdot \beta$, where $\beta$ is the cellbuffering power. 
the expressed protein, and the activation of endogenous conductance.

\section{Evidence for Ammonium Transport Mediated by the}

Human Erythroid Rh Glycoprotein A, RhAG

RhAG function was investigated in various cell models. Ammonium transport in RhAG-expressing X. laevis oocytes was first reported by Westoff et al. [23]: at extracellular $\mathrm{pH}, \mathrm{pH}_{\mathrm{o}}=7.5$, RhAG-expressing oocytes exhibited $\mathrm{a} \approx 10$-fold increase in MeA uptake, compared to control oocytes. Saturable MeA uptake was inhibited by ammonium $\left(\mathrm{IC}_{50}=1.1 \mathrm{mM}\right.$ at $\mathrm{pH}_{\mathrm{o}}$ 7.5), $\mathrm{pH}_{\mathrm{o}}$-dependent (increased by alkaline $\mathrm{pH}_{\mathrm{o}}$ and reduced by acid $\mathrm{pH}_{\mathrm{o}}$ ), and enhanced by maneuvers that acidify the cell. High $\mathrm{K}^{+}$medium (used to depolarize oocytes) had no effect on MeA flux. This finding, and an only small increase in RhAGexpressing oocyte conductance (but ammonium-induced currents were not checked), was considered as a reliable argument that that RhAG does not mediate an electrogenic ammonium transport. The authors concluded that RhAG mediates a coupled electroneutral $\mathrm{NH}_{4}{ }^{+} / \mathrm{H}^{+}$exchange, and that experimental data did not support $\mathrm{NH}_{3}$ transport [23]. By studying $\Delta$ Mep yeast transfected by $\mathrm{RhAG}$, the same group confirmed their conclusion that RhAG mediates a reversible $\mathrm{NH}_{4}{ }^{+} / \mathrm{H}^{+}$exchange [24].

At variance, Ripoche et al. [22] concluded that RhAG enhances $\mathrm{NH}_{3}$ influx in erythrocytes. To study RhAG function, control red ghost cells and in Rhnull ${ }^{7}$ red ghost cells were bathed in an ammonium-containing solution while $\mathrm{pH}_{\mathrm{i}}$ changes were measured using stopped-flow spectrofluorometry analysis (using the $\mathrm{pH}$-sensitive probe BCECF). This approach allows measurement of very fast changes in $\mathrm{pH}_{\mathrm{i}}$. The initial rate of ammoniuminduced $\mathrm{pH}_{\mathrm{i}}$ alkalization was slower in $\mathrm{Rh}$ null compared with control cells, consistent with a reduced $\mathrm{NH}_{3}$ influx in Rhnull cells. Also, a less pronounced secondary cell acidification during ammonium exposure was observed, but its mechanism was not further investigated. The authors concluded that RhAG expression facilitates $\mathrm{NH}_{3}$ transport in red blood cells [22].

In our laboratory, we expressed RhAG in HeLa cells. The $\mathrm{pH}_{\mathrm{i}}$ changes induced by a $10 \mathrm{mM} \mathrm{NH}_{4} \mathrm{Cl}$-containing solution were monitored using a video imaging system coupled to BCECF fluorescence. Compared to control

\footnotetext{
7 In the erythrocyte membrane, RhAG (Rhesus-associated glycoprotein) is associated with the proteins encoded by RHCE and RHD that carry RhD and $\mathrm{RhCcEe}$ antigens. Because $\mathrm{RhAG}$ expression is mandatory to surface expression of these antigens, some mutations in RHAG result in the Rhnull 'regulator' phenotype. For further details on Rhnull phenotypes and on $\mathrm{Rh}$ proteins in red blood cells, see Le Van Kim et al. [25].
}

cells, RhAG-expressing cells exhibit a faster initial alkalization, and an enhanced secondary acidification. This supports RhAG-induced enhanced $\mathrm{NH}_{3}$ and $\mathrm{NH}_{4}{ }^{+}$cell membrane respective permeabilities. The $\mathrm{pH}_{\mathrm{i}}$ recovery after withdrawal of a MeACl-containing solution also supported enhanced efflux of the neutral form in RhAGexpressing cells. We concluded that RhAG promotes a bidirectional transport of $\mathrm{NH}_{3}$, and enhances $\mathrm{NH}_{4}{ }^{+}$ transport [26]. Interestingly, when we expressed RhAG in X. laevis oocytes, low ammonium concentrations ${ }^{8}$ $(<1 \mathrm{mM})$ induced inward currents in voltage-clamped cells $(-50 \mathrm{mV})$, agreeing with $\mathrm{NH}_{4}{ }^{+}$-mediated current [27]. This observation is at variance from other reports using the same cell model $[28,29]$, but the reason(s) of this discrepancy is still unclear.

\section{Evidence for Ammonium Transport Mediated by the Human Non-Erythroid Rh Glycoproteins B and C, RhBG and RhCG}

The first report concerning the function of human epithelial Rh glycoprotein was obtained in our laboratory [30]. In RhCG-expressing oocytes, but not in control oocytes, submillimolar ammonium concentrations (from $0.1 \mathrm{mM}$ ) induced inward currents, consistent with $\mathrm{NH}_{4}{ }^{+}$ influx from bath to the cell. The amplitude of ammonium-induced current was voltage- and $\mathrm{pH}_{\mathrm{o}}$-dependent (increased at alkaline $\mathrm{pH}_{\mathrm{o}}$ and reduced at acid $\mathrm{pH}_{\mathrm{o}}$ ). Kinetic analysis of ammonium transport showed a saturable, high-affinity process: $\mathrm{K}_{\mathrm{m}}$ for $\mathrm{NH}_{3}$ was $\sim 8 \mu \mathrm{M}$, not dependent on $\mathrm{pH}_{\mathrm{o}}$ or on $\mathrm{NH}_{4}{ }^{+}$concentration, consistent with RhCG-mediated $\mathrm{NH}_{3}$ transport. Interestingly, $\mathrm{pH}_{\mathrm{i}}$ measurements (using pH-sensitive microelectrodes) revealed that low ammonium concentration induced an initial alkalization, followed by acidification in RhCGexpressing oocytes. The biphasic $\mathrm{pH}_{\mathrm{i}}$ change does not support simple $\mathrm{NH}_{3}-\mathrm{NH}_{4}{ }^{+}$co-transport, and suggests that RhCG-mediated $\mathrm{NH}_{3}$ and $\mathrm{NH}_{4}{ }^{+}$fluxes vary in an independent manner. This favors the hypothesis of uncoupled fluxes of $\mathrm{NH}_{3}$ and $\mathrm{NH}_{4}{ }^{+}$or of a bidirectional $\mathrm{NH}_{3}$ flux with $\mathrm{NH}_{4}{ }^{+}$influx [30]. Our conclusion is that RhCG mediates $\mathrm{NH}_{3}$ transport and induces $\mathrm{NH}_{4}{ }^{+}$transport. Further investigations confirmed that RhCG mediates bidirectional (i.e., influx and efflux) $\mathrm{NH}_{3}$ transport. Specificity of ammonium currents was also supported by the inhibitory effect of a mercurial derivative [Planelles et al., unpubl. results].

\footnotetext{
8 In $\mathrm{X}$. laevis oocytes at physiological $\mathrm{pH}_{\mathrm{o}}$, an ammonium concentration $>1 \mathrm{~mm}$ induces the activation of several endogenous transport systems, in particular a non-selective cationic conductance [for details, see 8].
} 
In RhBG- and in RhCG-transfected HEK cells, fast changes in $\mathrm{pH}_{\mathrm{i}}$ were monitored by others using stoppedflow analysis [31]. RhBG and RhCG expression enhances the initial cell alkalinization, a result fully consistent with an enhanced $\mathrm{NH}_{3}$ influx, induced by the expression of the human epithelial Rh glycoprotein. As it was the case when studying RhAG in red cells [22], the authors did not investigate the mechanism of the secondary acidification that they observed in HEK cells [31].

In RhBG-expressing oocytes a saturable, $\mathrm{pH}_{\mathrm{o}}$-dependent MeA uptake, inhibited by ammonium was reported. In this study, ammonium exposure induced inward currents in voltage-clamped oocytes, but it was concluded that these currents were related to the activation of endogenous $\mathrm{NH}_{4}{ }^{+}$channels, not to RhBG per se. Exposing RhBG-expressing and BCECF-loaded oocytes to a solution containing a submillimolar concentration of ammonium alkalinizes them in a stable manner (within minutes) without altering $\mathrm{pH}_{\mathrm{i}}$ in control oocytes [32]. Basically similar observations were obtained in RhCGexpressing oocytes by the same group and led the authors to conclude that RhBG as RhCG mediate an electroneutral $\mathrm{NH}_{4}{ }^{+} / \mathrm{H}^{+}$exchange [33].

\section{Conclusions}

Despite the bulk of recent knowledge, the precise function(s), substrate(s) and the mechanism(s) of transport of human Rh glycoproteins remain to be established. Up to now the studies of mouse Rh glycoproteins orthologs have not clarified the field: Rhbg and Rhcg have been reported to mediate electrogenic $\mathrm{NH}_{4}{ }^{+}$transport $[34,35]$ or electroneutral $\mathrm{NH}_{4}{ }^{+} / \mathrm{H}^{+}$exchange [36]. Several major questions will need to be addressed in the future. It will be important to establish whether or not Rh glycoproteins share the same function and to determine if they mediate direct $\mathrm{NH}_{3}$ transport (with or without associated or coupled $\mathrm{NH}_{4}{ }^{+}$transport) or indirect $\mathrm{NH}_{3}$ transport. It has been proposed that $\mathrm{NH}_{4}{ }^{+} / \mathrm{H}^{+}$counter-transport mediated by $\mathrm{Rh}$ glycoproteins is equivalent to net $\mathrm{NH}_{3}$ transport: the $\mathrm{NH}_{4}{ }^{+} / \mathrm{H}^{+}$exchange would consist in external $\mathrm{NH}_{4}{ }^{+}$binding to the transport protein, followed by its deprotonation and the proton being displaced into the external fluid $[29,36]$. This proposal, which needs further analysis, is an attempt to reconcile $\mathrm{NH}_{4}{ }^{+} / \mathrm{H}^{+}$exchange by Rh glycoproteins with the results of the analysis of the Amt crystal structure (see footnote 4 and references 12 and 13]. Conclusions from our laboratory that $\mathrm{Rh}$ glycoproteins mediate direct $\mathrm{NH}_{3}$ transport associ- ated with $\mathrm{NH}_{4}{ }^{+}$transport $[26,30]$ also need to be investigated further. Such a mechanism would be of interest, since the glutamine transporter $\mathrm{SN} 1$ is associated with a proton current that is associated not only with $\mathrm{SN} 1 \mathrm{ex}-$ pression, but also with its physiological function [37]. Lastly, if Rh glycoproteins mediate the direct transport of $\mathrm{NH}_{3}$, it is possible that they mediate the transport of other gases. Recent results suggest that $\mathrm{CO}_{2}$ permeability is increased in RhCG-expressing oocytes [27] and that Rhnull red blood cells have a lower $\mathrm{CO}_{2}$ permeability than control cells [17]. These results are consistent with the possibility that $\mathrm{Rh}$ glycoproteins can mediate $\mathrm{CO}_{2}$ transport and the concept that $\mathrm{Rh}$ glycoproteins have a wide physiological role. Future work, including exploration of transgenic animals (up to now only $\mathrm{Rhbg}^{-/-}$mice have been studied [38] and Rhbg disruption does not lead to an increase in plasma levels of ammonium or to renal distal tubular acidosis), will advance our understanding of these novel proteins.

\section{Acknowledgements}

This study was supported by Inserm and by Université Descartes-Paris 5. I am indebted to Dr. D. Hurvy for valuable stimulating discussions. 


\section{References}

1 Robinson, RA, Stockes RAH: Electrolyte Solutions, ed 2, rev. London, Butterworths, 1970, pp 1-517.

-2 Lang W, Block TM, Sander R: Solubility of $\mathrm{NH}_{3}$ and apparent $\mathrm{pK}$ of $\mathrm{NH}_{4}{ }^{+}$in human plasma, isotonic salt solutions and water at $37^{\circ}$. Clin Chim Acta 1998;273:43-58.

$\checkmark 3$ Binstock L, Lecar H: Ammonium ion currents in the squid giant axon. J Gen Physiol 1969;53:342-361.

$\checkmark 4$ Haussinger D: Liver regulation of acid base balance. Miner Electrolyte Metab 1997;23: 249-252.

5 Kinsella JL, Aronson PS: Interaction of $\mathrm{NH}_{4}{ }^{+}$ and $\mathrm{Li}^{+}$with the renal micovillus membrane Na-H exchanger. Am J Physiol 1981;241: C220-C226.

6 Knepper MA, Packer R, Good DW: Ammonium transport in the kidney. Physiol Rev 1989;69:179-249.

7 Nonoguchi H, Takehara Y, Endouh H: Intraand inter-nephron heterogeneity of ammoniogenesis in rat: effect of chronic metabolic acidosis and potassium depletion. Pflügers Arch 1987;407:245-251.

$\checkmark 8$ Cougnon M, Bouyer P, Hulin P, Anagnostopoulos T, Planelles G: Further investigation of ionic diffusive properties and of $\mathrm{NH}_{4}{ }^{+}$ pathways in Xenopus laevis oocyte cell membrane. Pflügers Arch 1996;431:658-667.

9 Cougnon M, Bouyer P, Jaisser F, Edelman A, Planelles G: Ammonium transport by the colonic $\mathrm{H}^{+}, \mathrm{K}^{+}$-ATPase expressed in Xenopus oocytes. Am J Physiol 1999;277:C280C287.

$\checkmark 10$ Kielland J: Individual activity coefficients in aqueous solutions. J Am Chem Soc 1937;59: 1675-1678.

-11 Peng J, Huang CH: Rh proteins vs. Amt proteins: an organismal and phylogenetic perspective on $\mathrm{CO}_{2}$ and $\mathrm{NH}_{3}$ gas channels. Trans Clin Biol 2006;13:85-94.

-12 Khademi S, O’Connell J, Remis J, RoblesColmenares Y, Miercke LJ, Stroud RM: Mechanism of ammonia transport by Amt/ MEP/Rh: structure of AmtB at $1.35 \AA$. Science 2004;305:1587-1594.

13 Zheng L, Kostrewa D, Bernèche S, Winkler FK, Li XD: The crystal structure of AmtB of E. coli suggests a mechanism for ammonia transport. Proc Natl Acad Sci 2004;101: 17090-17095.

-14 Cooper GJ, Zhou Y, Bouyer P, Gritchenko II, Boron WF: Transport of volatile solutes through AQP1. J Physiol 2002;542:17-29.
15 Blank ME, Ehmke H: Aquaporin-1 and $\mathrm{HCO}_{3}{ }^{-}-\mathrm{Cl}^{-}$transporter-mediated transport of $\mathrm{CO}_{2}$ across the human erythroid membrane. J Physiol 2003;550:419-429.

16 Nakhoul N, Hering-Smith KS, AbdoulnourNakhoul SM, Hamm LL: Transport of $\mathrm{NH}_{3} /$ $\mathrm{NH}_{4}{ }^{+}$in oocytes expressing aquaporin-1. Am J Physiol Renal 2001;281:F255-F263.

-17 Endeward V, Cartron JP, Ripoche P, Gross G: Red cell membrane $\mathrm{CO}_{2}$ permeability in normal blood and in blood deficient in various blood groups, and effect of DIDS. Trans Clin Biol 2006;13:123-127.

18 Holm LM, Jahn TP, Moller AL, Schjoerring JK, Ferri D, Klaerke DA, Zeuthen T: $\mathrm{NH}_{3}$ and $\mathrm{NH}_{4}{ }^{+}$permeabilily in aquaporin-expressing oocytes. Pflügers Arch 2005;450:415-428.

19 Marini AM, Urrestarazu A, Beauwens R, Andre B: The Rh (Rhesus) blood group polypeptides are related to $\mathrm{NH}_{4}{ }^{+}$transporters. Trends Biochem Sci 1997;22:460-461.

20 Marini AM, Matassi G, Raynal V, Andre B, Cartron JP, Chérif-Zahar B: The human Rhesus-associated RhAG protein and a kidney homologue promote ammonium transport in yeast. Nat Genet 2000;26:341-344.

21 Weiner ID, Verlander JW: Renal and hepatic expression of the ammonium transporter proteins, Rh B glycoprotein and $\mathrm{Rh} \mathrm{C}$ glycoprotein. Acta Physiol Scand 2003;179:331338.

22 Ripoche P, Bertrand O, Gane P, Birkenmeier C, Colin Y, Cartron JP: Human Rhesus-associated glycoprotein mediates facilitated transport of $\mathrm{NH}_{3}$ into red blood cells. Proc Natl Acad Sci USA 2004;101:17222-17227.

23 Westhoff CM, Ferreri-Jacobia M, Mak DO, Foskett JK: Identification of the erythrocyte Rh blood group as a mammalian ammonium transporter J Biol Chem 2002;277: 12499-12502.

24 Westhoff CM, Siegel DL, Burd CG, Foskett JK: Mechanism of genetic complementation of ammonium transport in yeast by human erythrocyte $\mathrm{Rh}$-associated glycoprotein. J Biol Chem 2004;279:17443-17448.

25 Le Van Kim C, Colin Y, Cartron JP: Rh proteins: key structural and functional components of the red cell membrane. Blood Rev 2006;20:93-110.

26 Benjelloun F, Bakouh N, Fritsch J, Hulin P, Lipecka J, Edelman A, Planelles G, Thomas SR, Chérif-Zahar B: Expression of the human erythroid Rh glycoprotein (RhAG) enhances both $\mathrm{NH}_{3}$ and $\mathrm{NH}_{4}{ }^{+}$transport in HeLa cells. Pflügers Arch 2005;450:155-167.

-27 Bakouh N, Benjelloun F, Chérif-Zahar B, Planelles G: The challenge of understanding ammonium homeostasis and the role of the Rh glycoproteins. Trans Clin Biol 2006;13: 139-146.
28 Westhoff CM, Wylie DE: Transport characteristics of mammalian Rh and Rh glycoproteins expressed in heterologous systems. Trans Clin Biol 2006;13:132-138.

29 Ludewig U: Ion transport versus ion conduction: function of AMT/Rh-type proteins. Trans Clin Biol 2006;13:111-116.

30 Bakouh N, Benjelloun F, Hulin P, Brouillard F, Edelman A, Chérif-Zahar B, Planelles G: $\mathrm{NH}_{3}$ is involved in $\mathrm{NH}_{4}{ }^{+}$transport induced by the functional expression of the human RhCG glycoprotein. J Biol Chem 2004;279: 15975-15983.

31 Zidi-Yahiaoui N, Mouro-Chanteloup I, D'Ambrosio AM, Lopez C, Gane P, Le Van Kim C, Cartron JP, Colin Y, Ripoche P: Human Rhesus B and Rhesus C glycoproteins: properties of facilitated ammonium transport in recombinant kidney cells. Biochem J 2005;391:33-40.

>32 Ludewig U: Electroneutral ammonium transport by basolateral Rhesus B glycoprotein. J Physiol 2004;559:751-759.

33 Mayer M, Schaaf G, Mouro I, Lopez C, Colin Y, Neumann P, Cartron JP, Ludewig U: Different transport mechanisms in plant and human AMT/Rh-type ammonium transporters. J Gen Physiol 2006;127:133-144.

34 Nakhoul NL, Dejong $\mathrm{H}$, AbdulnourNakhoul SM, Boulpaep EL, Hering-Smith K, Hamm LL: Characteristics of renal Rhbg as an $\mathrm{NH}_{4}{ }^{+}$transporter Am J Physiol Renal Physiol 2005;288:F170-F181.

35 Nakhoul NL, Schmidt E, AbdulnourNakhoul SM, Hamm LL: Electrogenic ammonium transport by renal Rhbg. Trans Clin Biol 2006;13:147-153.

36 Mak DOD, Dang B, Weiner ID, Foskett JK, Westhoff CM: Characterization of ammonium transport by the kidney Rh glycoproteins, RhBG and RhCG. Am J Physiol Renal Physiol 2006;290:F297-F305.

37 Chaudhry FA, Krizal D, Larsson P, Reimer R J, Wreden C, Storm-Mathisen J, Copenhagen D, Kavanhaugh M, Edwards R H: Coupled and uncoupled proton movement by amino acid transport system N. EMBO J 2001;20: 7041-7051

38 Chambrey R, Goossens D, Bourgeois S, Picard N, Bloch-Faure M, Leviel F, Geoffroy V, Cambillau M, Colin Y, Paillard M, Houillier P, Cartron JP, Eladari D: Genetic ablation of Rhbg in the mouse does not impair renal ammonium excretion. Am J Renal Physiol 2005;289:F1281-F1290. 